\title{
Stable nutrient flows in sustainable and alternative cropping systems of globe artichoke
}

\author{
Paola A. Deligios ${ }^{1} \cdot$ Maria Teresa Tiloca $^{1} \cdot$ Leonardo Sulas $^{2} \cdot$ Martina Buffa $^{1} \cdot$ \\ Stefano Caraffini ${ }^{3} \cdot$ Luca Doro $^{1,4}$ - Gavino Sanna ${ }^{1} \cdot$ Emanuela Spanu $^{1} \cdot$ Ester Spissu $^{1}$. \\ Giulia R. Urracci ${ }^{5}$ - Luigi Ledda ${ }^{1}$ (i)
}

Accepted: 9 October 2017 / Published online: 24 October 2017

(C) INRA and Springer-Verlag France SAS 2017

\begin{abstract}
The conventional cultivation of globe artichoke causes high nitrogen $(\mathrm{N})$ balance surpluses. The planning of more sustainable open-field horticultural systems (with no synthetic fertilizer supply) can contribute to the reduction of the nutrient surplus. We hypothesized that an artichoke conventional system could be shifted to a sustainable system through mineral fertilizer supply based on expected plant nutrient uptake, return of crop residues in well-defined growth phases, use of fertility-building crops, and crop rotations. Over a 10-year field experiment, three management systems, differing in fertilizer rates, crop sequence (monoculture/rotation with cauliflower), and legume cover crop adoption and management, were compared: (i) improved conventional, (ii) alternative monoculture, and (iii) biannual rotation. We monitored soil conditions at a sampling interval of approximately 3 years. We calculated gross $\mathrm{N}, \mathrm{P}$, and $\mathrm{K}$ balances for each growing season, and we also monitored soil respiration over the last two growing seasons. On average, the biannual rotation resulted in a well-balanced $\mathrm{N}$ budget $\left(72 \mathrm{~kg} \mathrm{ha}^{-1} \mathrm{~N}\right.$
\end{abstract}

Luigi Ledda

lledda@uniss.it

1 Department of Agriculture, Division of Agronomy and Plant Genetics, University of Sassari, Viale Italia 39, 07100 Sassari, Italy

2 Institute for Animal Production System in Mediterranean Environment (CNR-ISPAAM), Traversa La Crucca 3, località Baldinca, 07100 Sassari, Italy

3 Department for the Multifunctionality of Agricultural Enterprises, Rural Development \& Agrifood Chain Laore Agency of Sardinia-Laore Sardegna, Via Baldedda 11, 07100 Sassari, Italy

4 Blackland Research and Extension Center, Texas A\&M Agrilife Research, 720 East Blackland Road, Temple, TX 76502, USA

5 Department of Plant Science, Agricultural Research Agency of Sardinia-Agris Sardegna, Viale Trieste 111, 09123 Cagliari, Italy surplus) compared with improved conventional (160 kg $\mathrm{N} \mathrm{ha}{ }^{-1} \mathrm{~N}$ surplus) and alternative monoculture $\left(-34 \mathrm{~kg} \mathrm{ha}^{-1}\right.$ deficit) systems. By contrast, compared with the improved conventional system (133 and $116 \mathrm{~kg} \mathrm{ha}^{-1}$ for $\mathrm{P}$ and $\mathrm{K}$ budgets, respectively), alternative monoculture and biannual rotation systems had negative budgets for $\mathrm{P}\left(-9 \mathrm{~kg} \mathrm{ha}^{-1}\right.$ for both alternative systems) and $\mathrm{K}\left(-58\right.$ and $-51 \mathrm{~kg} \mathrm{ha}^{-1}$ for alternative monoculture and biannual rotation systems, respectively) in nine of ten growing seasons. Our results show for the first time that long-term biannual rotation with cauliflower coupled with cover crop use can optimize nutrient fluxes of conventionally grown globe artichoke. Overall, the study proposes a re-design of artichoke cropping systems, provides novel information useful for growers, and verifies that introducing a legume species cover crop is also the most promising approach to foster long-term sustainability.

Keywords Fertility-building crops · Gross nutrient balance . Soil respiration $\cdot$ Legumes $\cdot$ Long-term experiment

\section{Introduction}

Vegetable crop production is most often based on relatively intensive horticulture. Frequent tillage, use of large doses of synthetic fertilizers and pesticides, and poor soil coverage are common problems that challenge the maintenance of soil organic matter content and soil quality in this type of production system (EIP-AGRI Focus Group 2015). Given the very intensive production systems in which vegetables are typically grown, vegetable cropping is often associated with low nutrient use efficiencies and large nutrient losses. Excessive nitrogen $(\mathrm{N})$ applications can lead to the designation of new zones vulnerable to nitrates from agricultural pollution, which has previously occurred in some intensive horticultural areas 
(Cameira and Mota 2017). To improve environmental sustainability, a shift is required to other practices, which include increased inputs of organic amendments of either animal or plant origin, either produced on farm or bought from suppliers, use of cover crops or mulching, and possibly reduced tillage (EIP-AGRI Focus Group 2015). Sustainable agriculture management minimizes effects due to conventional systems and preserves the soil resilience in the long term (Gomiero et al. 2011). Cropping systems that include a legume cover crop also show positive effects by preventing $\mathrm{N}$ leaching and denitrification and by improving nutrient availability for the primary crop (Sánchez de Cima et al. 2015). Additionally, the incorporation of fresh crop residues characterized by a low carbon-to-nitrogen $(\mathrm{C} / \mathrm{N})$ ratio stimulates soil respiration and microorganism growth and triggers a rapid mineralization of nutrients, specifically nitrogen and phosphorus (P) (Turmel et al. 2015). Cynara cardunculus L. var. scolymus (L.) Fiori (globe artichoke) is an important vegetable crop primarily grown in Mediterranean countries for the large fleshy heads, as both a multi-year and annual crop depending on the cultivation area (Calabrese 2009). In southern Italy, an annual or a biennial crop cycle is adopted for autumn-tospring production (Calabrese 2009). In Sardinia, artichoke is primarily grown as an annual crop allowing growers to reach high economic gains because of earliness and the long productive cycle (from October-November to April, Pisanu et al. 2009) through the adoption of forcing technique (summer implantation by dormant offshoots, Ledda et al. 2013) and vegetatively propagated varietal types (e.g., "Spinoso Sardo"). The autumn-winter production is destined for fresh consumption, whereas the spring harvest is processed by industry (Sgroi et al. 2015). In globe artichoke, head production may vary depending on varietal type, plant density, and duration of the crop cycle but always represents a small part of the total biomass production (Llorach et al. 2002), which, at the end of each growing season, is usually grazed or burned (Ledda et al. 2013). In Italy, the globe artichoke crop, since the beginning of the twentieth century, has been widely grown in continuous monoculture heavily relying on synthetic fertilizer use (Calabrese 2009). Unfortunately, crop rotations that include soil-conserving crops are not used, and therefore, the same cultural practices are applied year after year leading to the artichoke monoculture cropping system. In this context, the systematic return of globe artichoke crop residues, introduction of cover crops, and rotation may be considered tools that can assure long-term nutrient supply and soil fertility. Moreover, these practices represent basic management options for the re-designing of alternative and more sustainable cropping systems for globe artichoke. The Organization for Economic Cooperation and Development (OECD 2007a, b) developed the gross nutrient balance as an indicator aimed at assessing environmental sustainability of alternative management practices in a long-term period. To better investigate interactions between organic matter dynamics and nutrient availability, soil respiration monitoring is a useful tool to evaluate the effects of alternative soil management practices on mineralization and humification dynamics (Almagro et al. 2009). Despite some contributions investigating globe artichoke response to mineral fertilization (Ierna et al. 2012), to our knowledge, only a few short-term attempts (Lenzi et al. 2015) have focused on planning innovative cropping systems. Therefore, in this study, we evaluated the long-term (10 years) sustainability of three globe artichoke management systems by combining information based on yearly nutrient fluxes. The specific objectives were the following: (1) to determine marketable artichoke yield and its components in different cultivation systems, (2) to calculate field gross nutrient balances for each management type, and (3) to analyze soil respiration to provide interpretation for the nutrient balance outcomes.

\section{Materials and methods}

\subsection{Site and experimental design}

The experimental field was established in 2006 at the experimental station "Mauro Deidda" near Sassari, Italy $\left(40^{\circ} 46^{\prime} \mathrm{N}\right.$, $8^{\circ} 29^{\prime} \mathrm{E} ; 81 \mathrm{~m}$ asl) (Fig. 1), and the experiment is ongoing. The climate is attenuated thermo-Mediterranean (Emberger et al. 1962) with a 4-month drought period in summer coinciding with the highest temperatures. Long-term (1954-2007) average rainfall is approximately $550 \mathrm{~mm}$ primarily distributed in autumn, whereas the maximum monthly temperature ranges between $14.8^{\circ} \mathrm{C}$ (January) and $30.6{ }^{\circ} \mathrm{C}$ (July) and the minimum temperature between $7.8^{\circ} \mathrm{C}$ (January) and $22.3{ }^{\circ} \mathrm{C}$ (August). A gradual increase in average minimum temperature $\left(+1.6^{\circ} \mathrm{C}\right.$ above the $1954-2007$ long-term series $)$ occurred over the 10-year period but no marked changes in precipitation and average maximum temperature. The soil, classified as a Lithic Xerochrept (USDA 1999), had a pH value of 7.9 with sand and clay contents of 489 and $196 \mathrm{~g} \mathrm{~kg}^{-1}$, respectively, and electrical conductivity of $0.21 \mathrm{mS} \mathrm{cm}^{-1}$ at 0 - to 40 $\mathrm{cm}$ depth. Cation exchange capacity was $27.1 \mathrm{meq}$ per $100 \mathrm{~g}$ of dry soil with large amounts of calcium and magnesium (23.3 and $2.3 \mathrm{mg} \mathrm{kg}^{-1}$, respectively). As a percentage of soil dry weight, soil water contents were 22.4 and $11.9 \%$ at field capacity and permanent wilting point, respectively. The following three cropping systems were studied: an improved conventional system, an alternative monoculture system, and a biannual rotation system. The three cropping systems were arranged in a completely randomized block design with three replicates. Blocks and plots were separated by approximately $3 \mathrm{~m}$ to avoid interaction effects and cross-contaminations among the differently managed systems as much as possible. To reflect the traditional forcing technique (Ledda et al. 2013), 


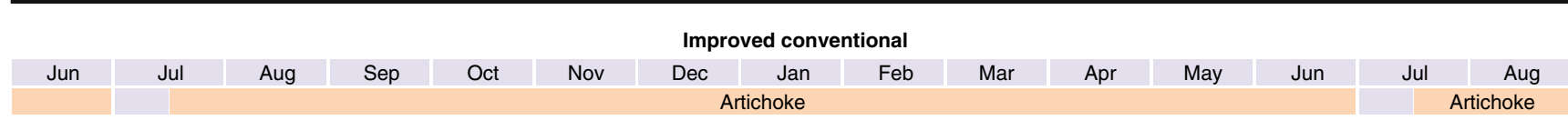

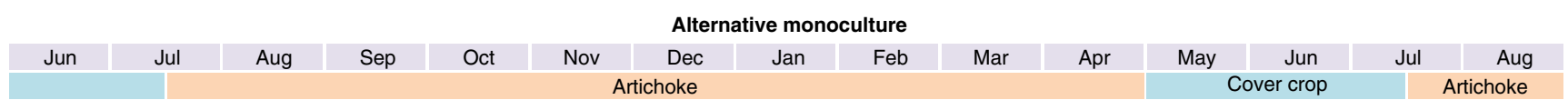

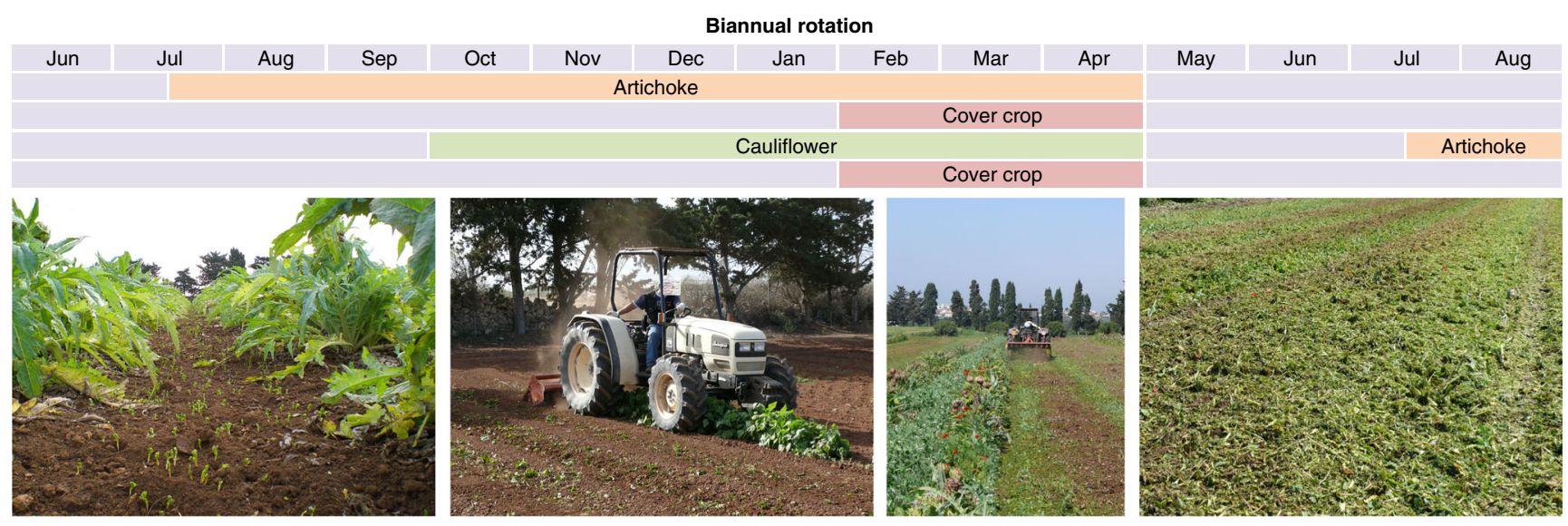

Fig. 1 Above: overview of the experiment setup. Below: field study (cover crop emergence; fresh residues chopping and incorporating into the soil) conducted at the University of Sassari experimental station "Mauro Deidda" in Ottava, Sassari

beginning in 2006, after soil preparation by plowing and harrowing, a total of 0.4 ha was annually planted within the last 10 days of July with 15 -cm-long semi-dormant offshoots of Spinoso Sardo artichoke. The distance between plants within a row was $70 \mathrm{~cm}$, achieving an overall density of 9524 plants $\mathrm{ha}^{-1}$. Drip irrigation was applied to the entire experimental field (when accumulated daily evaporation reached $35 \mathrm{~mm}, 100 \%$ of maximum evapotranspiration) from the date of planting to the first rainfalls. The improved conventional system was yearly managed in continuous monoculture and with incorporation of dried plant residues into the soil by chopping and harrowing up to a $20-\mathrm{cm}$ depth at the end of the crop cycle (end of June). Application rates of N, P, and potassium $(\mathrm{K})$ were calculated from crop macronutrient uptake, which reflects the synchronization of crop nutrient requirements and soil macronutrient supply (Piras 2013). Averaging across years, total $\mathrm{N}, \mathrm{P}$, and $\mathrm{K}$ applied during the field experiment were 150,125 , and $140 \mathrm{~kg} \mathrm{ha}^{-1}$, respectively. Fertilizers were applied in four split doses at planting, midSeptember, late-November, and late-February. Pest and disease controls followed the regional recommendations (Pisanu et al. 2009; Spanu et al. 2017). Weed control was achieved by mechanical means. The alternative monoculture and biannual rotation systems were conducted without synthetic pesticide and fertilizer use. In the alternative monoculture system, the artichoke-growing cycle was interrupted early at the end of the marketable harvest period (mid-April), and the fresh residues were chopped and plowed under. A shortcycle legume, French bean (Phaseolus vulgaris L. cv. Bronco) (Monsanto Agricoltura Italia SpA, Italy), was introduced both for the additional income and for the $\mathrm{N}$ supply. Indeed, the French bean was terminated at the reproductive stage, when plants produced the first pods (end of flowering). Fresh residues from this bean crop were also incorporated into the soil (end of June) by harrowing before the new growing season for artichoke began. The biannual rotation was based on a 2-year artichoke rotation with cauliflower (Brassica oleracea L. var. botrytis cv. Nautilus) (Clause Italia SpA, Italy). Both species were investigated on alternate plots; thus, all phases of the crop sequence were present in the field every year. Pea (Pisum sativum L. cv. Attika) (Limagrain Verneuil Holding, France) as a legume cover crop was undersown with artichoke and cauliflower in February. At the end of the primary crop marketable harvest period and when pea was flowering (midApril), all artichoke, cauliflower, and pea fresh residues were incorporated into the soil. Two months after incorporation, the beds in all plots were rotary-tilled for the next cauliflower or artichoke production cycle. No mineral fertilization or weed, pest, and disease controls were performed for the alternative monoculture and biannual rotation managements, except in the 2013-2014 growing season, when a chicken manure application supplied 107, 141, and $146 \mathrm{~kg}$ of $\mathrm{N}, \mathrm{P}$, and $\mathrm{K}$ $\mathrm{ha}^{-1}$ year $^{-1}$, respectively.

\subsection{Globe artichoke marketable yield and its components}

For head biometric characterization and yield determination, marketable early heads were picked immediately before bract divergence (stage D, Foury 1967). Harvest began on each plot in November and continued for approximately 3 months 
because only early production characterized by the highest market price was considered. The average yield per plant was multiplied by crop density for absolute yield estimation.

\subsection{Long-term variations in soil quality and nutrients}

Soil was sampled in 2006 to assess initial soil conditions, in 2009 and 2013, and at the end of the last crop cycle in 2016. In each plot, four composite soil samples, of 4-cm diameter, were collected at 0-20- and 20-40-cm depths. After air-drying and sieving $(2 \mathrm{~mm}$ ), soil samples were analyzed for $\mathrm{pH}$, organic matter, total nitrogen, available phosphorus, and exchangeable potassium in accordance with the standard methods of the Italian Soil Science Society (2000).

\subsection{Gross nutrient balances}

The field gross nutrient balances were evaluated following the criteria proposed by OECD (2007a, b) and AndristRangel et al. (2007) for the calculation of the surface input/output balances of $\mathrm{N}, \mathrm{P}$, and $\mathrm{K}$. Concerning the $\mathrm{N}$ balance, fertilizers, biologically fixed $\mathrm{N}$, and atmospheric deposition of $\mathrm{N}$ compounds were included as inputs, whereas marketed yield products were the outputs (OECD 2007a, b). For P and K balances, fixed elements by symbionts were omitted. The amounts $\left(\mathrm{kg} \mathrm{ha}^{-1}\right)$ of N, P, and $\mathrm{K}$ applied to the crops by fertilizers were recorded yearly. Concentrations of N, P, and K declared by the manufacturers were used for the mineral fertilizer and poultry manure. Annual atmospheric deposition rates of $\mathrm{N}$ and $\mathrm{P}$ were derived from Markaki et al. (2010). The mean flow rates for 2001 and 2002 reported by Markaki et al. (2010) for the entire region were used for the entire duration of the experiment. Following Andrist-Rangel et al. (2007), K depositions were not included in the calculation because estimates are very small (Morselli et al. 2008; Nastos et al. 2007). The proportion of $\mathrm{N}$ derived from the atmosphere (\%Ndfa) in each plant organ of French bean and pea was quantified in the field according to the ${ }^{15} \mathrm{~N}$ isotopic dilution method (Warembourg 1993). Finally, the amount of fixed $\mathrm{N}\left(\mathrm{kg} \mathrm{ha}^{-1}\right)$ was calculated by multiplying French bean and pea $\mathrm{N}$ yields $\left(\mathrm{kg} \mathrm{N} \mathrm{ha}^{-1}\right)$ by $\% \mathrm{Ndfa}$. The samples of cover crop aboveground biomass were collected in a $0.5-\mathrm{m}^{2}$ central area of each plot immediately before incorporation into the soil. Cauliflower and French bean marketable production data were determined for each growing season by harvesting six plants per plot at weekly intervals throughout the harvest period (Fig. 1). The average yield per plant was multiplied by crop density for absolute yield $\left(\mathrm{kg} \mathrm{ha}^{-1}\right)$ estimation. Total $\mathrm{N}$ concentration in the samples was measured by dry combustion in an elemental analyzer LECO 628 (628 Series; LECO Corp., St. Joseph, MI, USA). Phosphorus and potassium were determined according to AOAC methods (1995). Nitrogen, P, and K outputs per hectare of head and pod yields were calculated by multiplying their own element contents by the aerial biomass value (dry-weight basis). The results are expressed on a per-year basis. The results of gross balances were either positive, indicating nutrient accumulation in the soil, or negative, indicating nutrient depletion from the soil.

\subsection{Soil respiration response to cropping systems}

To create an area without plant roots, we installed a $40-\mathrm{cm}$ diameter PVC collar to a depth of $40 \mathrm{~cm}$ in each experimental plot in October 2014. To prevent re-growth, we kept the collar covered with brown non-woven spun bond. Respiration was measured between 1000 and $1400 \mathrm{~h}$ in a small PVC collar $(10 \mathrm{~cm}$ in diameter and $10 \mathrm{~cm}$ in height) installed $2-3 \mathrm{~cm}$ into the soil within the larger collar. Soil respiration monitoring was conducted 8 years after the beginning of the experiment, when soil organic matter had apparently reached a relatively steady state. Measurements were conducted weekly over 12 months using an SRC1 (PP Systems, Hertfordshire, UK) closed chamber connected to a portable infrared gas analyzer (IRGA) EGM-4 (PP Systems, Hertfordshire, UK). The rate of soil $\mathrm{CO}_{2}$ efflux was obtained using the PP system software, which fitted a quadratic equation to the increase of $\mathrm{CO}_{2}$ concentration in the chamber recorded every $124 \mathrm{~s}$. The mean value of three repeated measurements was used as the reading for each collar. The soil temperature close to the chamber was measured simultaneously with the measurement of $\mathrm{CO}_{2}$ at a depth of $5 \mathrm{~cm}$ using an STP-1 soil temperature probe connected to an EGM-4 instrument. The soil volume-water content near the chamber was also measured simultaneously with the measurement of $\mathrm{CO}_{2}$ at a depth of $20 \mathrm{~cm}$ using a TDR 300 soil moisture meter (Spectrum Technologies, Inc., Plainfield, IL, USA).

\subsection{Statistical analyses}

Data of dependent variables were subjected to analysis of variance using the MIXED procedure (SAS v 9.2 1999). Blocks were considered a random effect factor, whereas the three management systems and the ten crop seasons were considered fixed-effect factors. The repeated recordings of $\mathrm{CO}_{2}$ flux, soil temperature, and moisture data over time in the same plots were accounted for by including these data as repeated effects. An autoregressive correlation structure and variance were assumed between data of samplings. Significance was determined using the $F$ statistic, and $\alpha=0.05$. The denominator degrees of freedom in the $F$ test for mean separation were calculated according to Kenward and Roger (1997). All data, when necessary, were logtransformed to obtain homogeneity of variance. 


\section{Results and discussion}

\subsection{Globe artichoke marketable yield and its components}

Significant year $\times$ cropping system interactions (Table 1) were detected for marketable head yield, number, and weight. Marketable yield was higher in nine of ten growing seasons in the alternative monoculture system than that in the other two systems. Consistent with the positive effect on total yield, the number of heads was also higher in the alternative monoculture than that in the other two systems. Additionally, the alternative monoculture showed the earliest production (averaged over the studied period), which allows growers to obtain high and remunerative prices within the Italian market (data not shown). Head weight was more variable than that of the number and was higher in the improved conventional system in 2008 and 2011 than in the other growing seasons (Table 1). A significantly higher proportion of heads with atrophy (in the range 5.9-6.5\%) within the improved conventional treatment could explain the difference in total head yield and number among treatments and over the ten growing seasons. Several environmental conditions can lead to this physiological head disorder (Francois et al. 1991; Mauro et al. 2008). Our results for the improved conventional system are consistent with the findings of Shinohara et al. (2011) who observed a significantly higher proportion of heads with tip burn or atrophy in highthan low-N-rate treatments. Moreover, Leavitt et al. (2011) found that marketable yields were reduced compared with a control without a cover crop, as a result of fewer growing degree-days, which delayed early vegetable growth resulting in reduced yields. However, variation in summer (from planting to flower induction in the last 10 days of September) maximum temperature could be also responsible for major yield fluctuations across years. In both growing seasons with the lowest yields (2009-2010 and 2010-2011, Table 1), the maximum temperature was $1.5{ }^{\circ} \mathrm{C}$ (average from July to September) above the long-term weather series. By contrast, the relatively high yield across all treatments (Table 1) in the last two seasons (2014-2015 and 2015-2016) was related to the highest average maximum temperature in winter months $\left(+1.5^{\circ} \mathrm{C}\right)$ and with no freeze event. Similarly, in a short-term experiment, Ledda et al. (2003) ascribed the high temporal variability of artichoke yields to the average maximum temperature encountered during the flower induction period. However, for a zucchini crop, although the variability of weather conditions between years may have affected total and marketable yields, cover crop management and organic fertilizers also caused significant effects (Montemurro et al. 2013). Our results demonstrated for globe artichoke that when weather conditions during the development of heads were fairly similar to historical weather trends, productivity was relatively stable and therefore provided a stable supply of early heads during long-term cultivation. Indeed, when the maximum temperature during the summer months (negative influence) or during the winter months (positive influence) greatly exceeded the long-term maximum temperature values, we observed that globe artichoke production was dependent primarily on weather conditions rather than the management of the crop.

\subsection{Long-term variations in soil quality and nutrients}

Because soil properties were consistent across the 10 years between artichoke and cauliflower plots in the biannual rotation, only average data are discussed herein. A significant difference in soil $\mathrm{pH}$ among managements was detected during 2006 only. When soil is slightly alkaline, as in our study, a potential reduction in $\mathrm{pH}$ depends very much on the buffering capacity of the soil and over the long-term, a decrease in $\mathrm{pH}$ may not occur (James 2005). In our long-term experiment, two systems of monoculture (improved conventional and alternative monoculture) had significantly higher soil organic matter content (Table 2) than that of the biannual rotation system, and the alternative monoculture system was the only alternative to the improved conventional treatment which successfully accrued soil organic matter over time. In the biannual rotation, we hypothesized that soil organic matter was more likely to be maintained over time. The biannual rotation system had amounts of residues that were comparable with those of conventional and alternative monocultures; however, the likely low $\mathrm{C} / \mathrm{N}$ ratio of the pea cover crop $(\leq 15$ according to Murungu et al. 2011) led to more rapid biomass decomposition and less organic matter storage than those in the improved conventional and alternative monoculture system. This hypothesis is consistent with the observations of Pavek (2012) who found that pea biomass decomposed very quickly because of the low plant $\mathrm{C} / \mathrm{N}$ ratio and did not increase soil organic matter over the long term. However, some models suggest that high-quality residues easily incorporated into microbial biomass may lead to more long-term soil organic matter storage (Cotrufo et al. 2013). The total organic $\mathrm{C}$ content between the initial soil conditions and that in 2016 was not significantly different, whereas significant differences were found among cropping systems in 2013 and 2016 (Table 2), with the same pattern previously demonstrated for soil organic matter. Total $\mathrm{N}$ concentration was not significantly different among treatments. Significant differences were found compared with initial soil conditions in 2006 (Table 2), with the highest values observed in the establishment year, and total $\mathrm{N}$ concentration was significantly lower in the improved conventional system. Here, we hypothesize that because microbial growth requires carbon for energy and $\mathrm{N}$ to build proteins, when aboveground biomass with a high $\mathrm{C} / \mathrm{N}$ ratio is incorporated (approximately 24 , according to Mahmoud and Abd El-Kader 2012), N is not available from the newly added organic material, and therefore, microbes 
Table 1 The effect of year $\times$ management interaction on the marketable yield, head numbers, and mean head weight

\begin{tabular}{|c|c|c|c|c|c|c|c|c|c|}
\hline \multirow[t]{2}{*}{ Years } & \multicolumn{3}{|c|}{ Marketable yield $\left(\mathrm{kg} \mathrm{ha}^{-1}\right)$} & \multicolumn{3}{|c|}{ Heads numbers (plant ${ }^{-1}$ ) } & \multicolumn{3}{|c|}{ Mean head weight (g) } \\
\hline & $\begin{array}{l}\text { Improved } \\
\text { conventional }\end{array}$ & $\begin{array}{l}\text { Alternative } \\
\text { monoculture }\end{array}$ & $\begin{array}{l}\text { Biannual } \\
\text { rotation }\end{array}$ & $\begin{array}{l}\text { Improved } \\
\text { conventional }\end{array}$ & $\begin{array}{l}\text { Alternative } \\
\text { monoculture }\end{array}$ & $\begin{array}{l}\text { Biannual } \\
\text { rotation }\end{array}$ & $\begin{array}{l}\text { Improved } \\
\text { conventional }\end{array}$ & $\begin{array}{l}\text { Alternative } \\
\text { monoculture }\end{array}$ & $\begin{array}{l}\text { Biannual } \\
\text { rotation }\end{array}$ \\
\hline 2006 & $1180 \mathrm{bB}$ & $1378 \mathrm{fA}$ & $1135 \mathrm{~dB}$ & $6.2 \mathrm{a}$ & $6.3 \mathrm{c}$ & $5.7 \mathrm{c}$ & $87.9 \mathrm{~d}$ & $85.2 \mathrm{~d}$ & $84.2 \mathrm{~d}$ \\
\hline 2007 & $1207 \mathrm{bB}$ & $1640 \mathrm{dA}$ & $1224 \mathrm{~dB}$ & $6.3 \mathrm{aB}$ & $7.6 \mathrm{bA}$ & $6.3 \mathrm{bB}$ & $89.4 \mathrm{~dB}$ & $102.0 \mathrm{cA}$ & $91.0 \mathrm{~dB}$ \\
\hline 2008 & $940 \mathrm{cC}$ & $1573 \mathrm{eA}$ & $1238 \mathrm{~dB}$ & $5.0 \mathrm{bC}$ & $7.2 \mathrm{bA}$ & $6.4 \mathrm{bB}$ & $126.0 \mathrm{bA}$ & $97.0 \mathrm{cB}$ & $93.0 \mathrm{~dB}$ \\
\hline 2009 & $748 \mathrm{dC}$ & $1107 \mathrm{gA}$ & $872 \mathrm{eB}$ & $3.9 \mathrm{cB}$ & $5.1 \mathrm{dA}$ & $4.1 \mathrm{~dB}$ & $103.5 \mathrm{cB}$ & $78.7 \mathrm{dC}$ & $123.0 \mathrm{bA}$ \\
\hline 2010 & $560 \mathrm{eB}$ & $934 \mathrm{gA}$ & $981 \mathrm{eA}$ & $2.9 \mathrm{~dB}$ & $4.3 \mathrm{eA}$ & $4.6 \mathrm{dA}$ & $79.5 \mathrm{eC}$ & $125.3 \mathrm{aB}$ & $138.0 \mathrm{aA}$ \\
\hline 2011 & $1157 \mathrm{bB}$ & $2051 \mathrm{bA}$ & $1967 \mathrm{bA}$ & $6.0 \mathrm{aB}$ & $9.4 \mathrm{aA}$ & $9.8 \mathrm{aA}$ & $162.3 \mathrm{aA}$ & $126.0 \mathrm{aB}$ & $61.2 \mathrm{eC}$ \\
\hline 2012 & $771 \mathrm{~dB}$ & $1480 \mathrm{eA}$ & $1478 \mathrm{cA}$ & $6.1 \mathrm{aB}$ & $9.4 \mathrm{aA}$ & $9.6 \mathrm{aA}$ & $103.0 \mathrm{cA}$ & $110.3 \mathrm{bA}$ & $90.9 \mathrm{~dB}$ \\
\hline 2013 & $776 \mathrm{dC}$ & $1800 \mathrm{cB}$ & $2343 \mathrm{bA}$ & $6.1 \mathrm{aB}$ & $9.4 \mathrm{aA}$ & $9.8 \mathrm{aA}$ & $106.0 \mathrm{cA}$ & $112.0 \mathrm{bA}$ & $72.3 \mathrm{eB}$ \\
\hline 2014 & $2453 \mathrm{aC}$ & $3479 \mathrm{aA}$ & $3253 \mathrm{aB}$ & $5.2 \mathrm{bB}$ & $7.1 \mathrm{bA}$ & $6.7 \mathrm{bA}$ & $75.0 \mathrm{eB}$ & $110.3 \mathrm{bA}$ & $110.2 \mathrm{cA}$ \\
\hline 2015 & $2514 \mathrm{aC}$ & $3457 \mathrm{aA}$ & $3270 \mathrm{aB}$ & $6.1 \mathrm{aB}$ & $9.4 \mathrm{aA}$ & $9.8 \mathrm{aA}$ & $75.6 \mathrm{eB}$ & $102.7 \mathrm{cA}$ & $101.6 \mathrm{cA}$ \\
\hline \multicolumn{10}{|l|}{ LSMEANS test } \\
\hline Years & $* * *$ & & & $* * *$ & & & $* * *$ & & \\
\hline Management & $* * *$ & & & $* * *$ & & & $* * *$ & & \\
\hline $\begin{array}{l}\text { Years } \times \\
\text { management }\end{array}$ & $* * *$ & & & $* * *$ & & & $* *$ & & \\
\hline
\end{tabular}

Values without common letters are statistically different according to LSMEANS $(P \leq 0.05)$ in rows for each cropping system (uppercase letter) and columns for each year (lowercase letters)

$* \mathrm{P} \leq 0.05 ; * * P \leq 0.01 ; * * * P \leq 0.001$

must obtain $\mathrm{N}$ from the soil, depriving growing plants of $\mathrm{N}$. This finding was consistent with no positive effect, on average, of the improved conventional treatment on yield, head number, or head weight. The unexpected values recorded in both alternative systems were most likely the result of cover crop and artichoke fresh aboveground biomass that progressively mineralized and increased the available $\mathrm{N}$ content following incorporation into the soil. Some authors (Tonitto et al. 2006; Montemurro et al. 2013) report that legumes can contribute up to $300 \mathrm{~kg} \mathrm{~N} \mathrm{ha}^{-1}$. Although much of this $\mathrm{N}$ is from aboveground biomass, pea root biomass may be as much as $12 \%$ of aboveground biomass (Montemurro et al. 2013), which decomposes more slowly belowground. Overall, importantly, intercropping with legumes is recognized as a powerful way to promote a more diversified plant community in the field, which enables complementary and facilitative processes while providing valuable ecological services (Duchene et al. 2017). To maintain $P$ availability to artichoke on calcareous soils, $\mathrm{P}$ fertilizer was applied on a regular basis in the improved conventional system, which therefore avoided the significant decrease in P compared with initial soil conditions that we observed in alternative monoculture and biannual rotation systems. Similar results were reported for a long-term study (Ohm et al. 2017), in which a 12 -year negative $P$ budget reduced the level of plant-available $\mathrm{P}$ in soils of all organic farming systems, demonstrating that increasing the percentages of forage legumes and manure recycling in mixed arable crop rotations and grasslands does not necessarily mitigate decreases of plant-available P. Exchangeable K (Table 2) decreased over the experimental period, reaching the lowest value at the end of the experiment and in both of the unfertilized systems. With the decrease in K over the experimental period, some crop uptake of $\mathrm{K}$ released from the non-exchangeable pool likely occurred, as also hypothesized by Andrist-Rangel et al. (2007) in their long-term experiment. This phenomenon, previously reported by Kautz et al. (2013), could be explained as a consequence of the biocycling of subsoil $\mathrm{K}$, characterized by the slow release from available potassium sources.

\subsection{Gross nutrient balances}

Because of the significant interactions between treatments and years for all the analyzed nutrient balances, data were reanalyzed by year (Fig. 2). In the improved conventional system, the annual gross $\mathrm{N}$ balance (and that for $\mathrm{P}$ and $\mathrm{K}$ ) was relatively consistent over the years and was positive for all the analyzed growing seasons (Fig. 2) with an average surplus of $160 \mathrm{~kg} \mathrm{~N} \mathrm{ha}^{-1}$ (ranging from 123 to $183 \mathrm{~kg} \mathrm{ha}^{-1}$ ). Significant differences were also detected in mean $\mathrm{P}$ and $\mathrm{K}$ surpluses among years (in the ranges of $127-136$ and $82-135 \mathrm{~kg} \mathrm{ha}^{-1}$ for $\mathrm{P}$ and $\mathrm{K}$, respectively). In eight of ten growing seasons, the alternative monoculture had a calculated $\mathrm{N}$ deficit that ranged from -3.8 to $-28.5 \mathrm{~kg} \mathrm{ha}^{-1}$, and a surplus of $\mathrm{N}$ occurred only in 2009-2010 and 2013-2014 (7.1 and $89 \mathrm{~kg} \mathrm{ha}^{-1}$, 


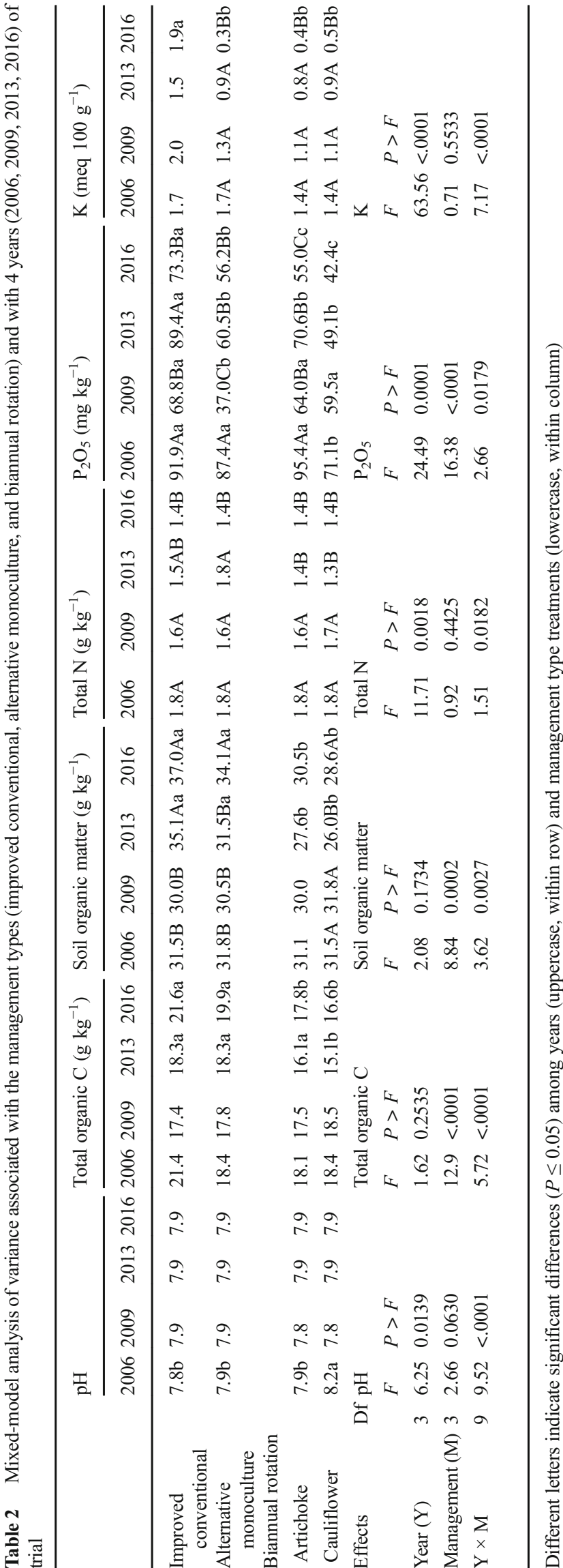

respectively, Fig. 2). In the biannual rotation system, the $\mathrm{N}$ balance was always positive (average $72 \mathrm{~kg} \mathrm{ha}^{-1}$ ), except for the 2007-2008 growing season in the plots of rotational artichoke $\left(-21 \mathrm{~kg} \mathrm{ha}^{-1}\right)$. Balances of $\mathrm{P}$ and $\mathrm{K}$ in the alternative monoculture (average -9 and $-58 \mathrm{~kg} \mathrm{ha}^{-1}$ for $\mathrm{P}$ and $\mathrm{K}$, respectively) and the biannual rotation (average -9 and $-51 \mathrm{~kg} \mathrm{ha}^{-1}$ for $\mathrm{P}$ and $\mathrm{K}$, respectively) were negative in all years, except in 2013-2014, when the total deficit of N, P, and $\mathrm{K}$ was replenished by supplying chicken manure (Fig. 2). The amount of $\mathrm{N}$ that is supplied in excess of vegetable crop requirements and cannot be fixed in the soil is prone to reach adjacent ecosystems and cause water pollution (Cameira and Mota 2017). Based on the N surplus indicator, the improved conventional system had a remarkable excess of $\mathrm{N}$ compared with the alternative monoculture $(+102 \%)$ and the biannual rotation (+ 44\%). According to Sulas et al. (2012), N losses due to leaching were more than negligible in a nearby area, particularly in autumn. In the alternative monoculture, the high production was maintained at the cost of the soil organic $\mathrm{N}$ pool. This result might be primarily associated with the management of the French bean crop, because the marketed pods, in addition to an output in the balance, also represented a net removal from the field of a relevant amount of $\mathrm{N}$ that was biologically fixed by that legume. The extent of the French bean fresh pod harvest could be considered a further management option linked to the amount of $\mathrm{N}$ that was removed or left within the cropping system. In fact, with marketable pods left in the field (or performing a partial harvest), the gross $\mathrm{N}$ balance would have ranged from +11 to $-11 \mathrm{~kg} \mathrm{ha}^{-1}$ (almost neutral in the decade), with the balance only slightly negative for 2 years in the 10-year period (data not shown). In our nonfertilized systems, a positive $\mathrm{N}$ balance (outputs $>$ inputs) was observed in the biannual-based rotation, which indicated appropriate nutrient management. The positive $\mathrm{N}$ balance was primarily due to the effect of the amount and quality (i.e., a low $\mathrm{C} / \mathrm{N}$ ratio) of fresh crop residues returned to the soil, which was also found by Constantin et al. (2010). After 10 years of cultivation in the biannual rotation, we found that the retention of residues maintained a high and relatively stable agronomic productivity and use efficiency of $\mathrm{N}$ inputs, thereby increasing sustainability. The pattern of the $\mathrm{P}$ and $\mathrm{K}$ budgets was similar, but the balance differed significantly between conventionally and alternatively managed systems. Alternative monoculture and biannual rotation systems had calculated $\mathrm{P}$ and $\mathrm{K}$ deficits, whereas the conventional system apparently accumulated both $\mathrm{P}$ and $\mathrm{K}$. However, the deficiency of $\mathrm{P}$ and $\mathrm{K}$ in the unfertilized systems was small, and organic replenishment fertilization was only applied after 8 years from the beginning of the experiment. For P, our results might be explained by the fact that cover crops can increase internal $\mathrm{P}$ recycling via soil $\mathrm{P}$ mobilization, which was observed by Maltais-Landry et al. (2016) in their long-term trial. In our study, cover crops were incorporated into the soil 

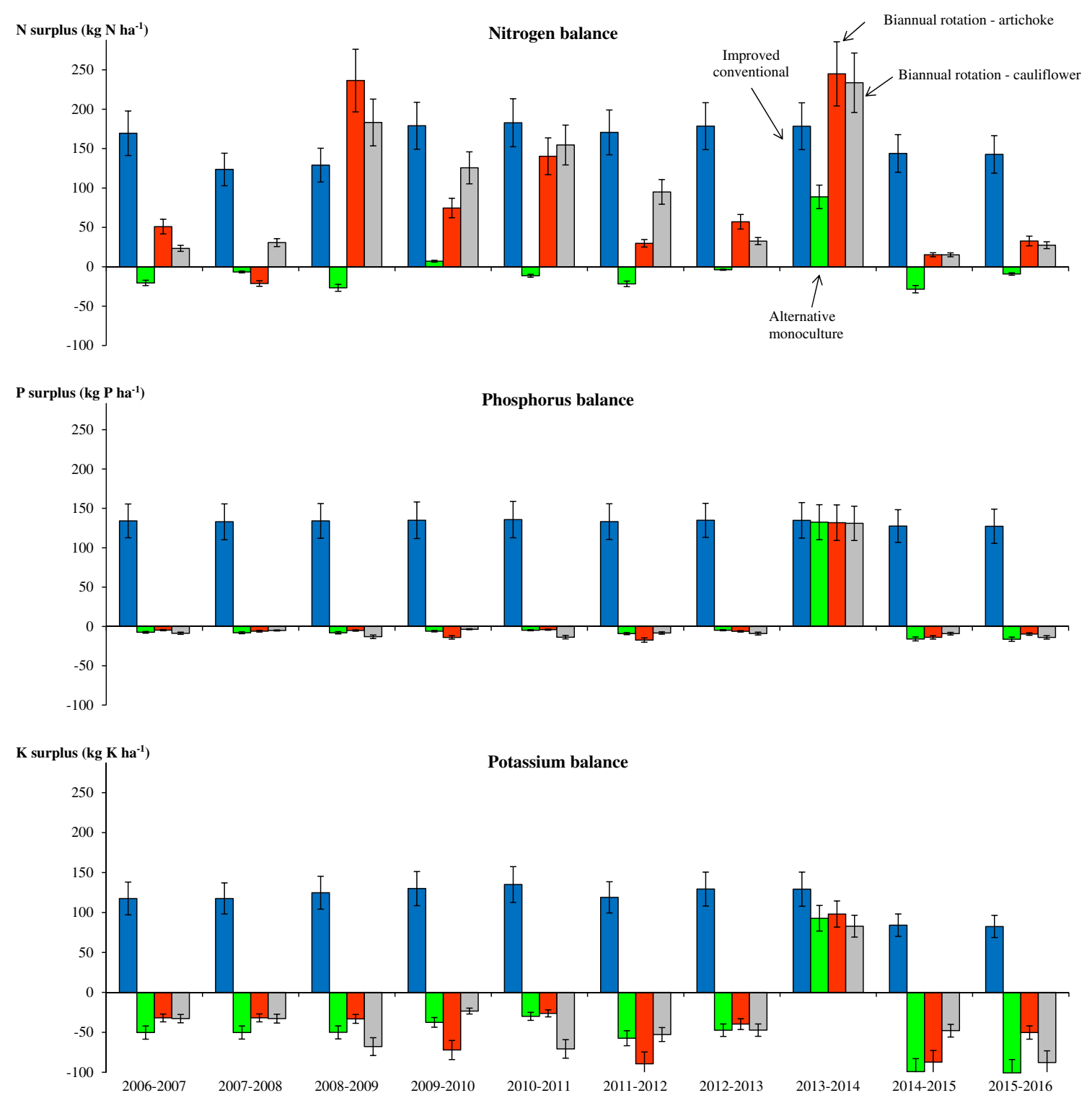

Growing seasons

Fig. 2 Gross N (nitrogen: upper subplot), P (phosphorus: middle subplot), and $\mathrm{K}$ (potassium: lower subplot) balances for improved conventional (blue bars), alternative monoculture (green bars), and biannual rotation (red bars for artichoke and gray for cauliflower) over the 10 -year period. Error bars indicate standard error of the means only a few weeks before planting of subsequent crops to better synchronize residue nutrient release and nutrient uptake for the subsequent crop, which was also suggested by Cavigelli and Thien (2003) and Simpson et al. (2011). By contrast, in the improved conventional system, fertilizers applied to the field in excess of plant requirements resulted in substantial accumulation of soil $\mathrm{P}$, although our results are consistent with $\mathrm{P}$ surpluses that also occurred with mineral fertilizers (Shen et al. 2014) and in conventional production with other vegetables (Nesme et al. 2011; Yan et al. 2013). Based on the soil K system budgets, the improved conventional system had unnecessarily high levels of $\mathrm{K}$ fertilization, which was also observed by Korsaeth (2012) for arable conventional systems in a 10-year trial. In the unfertilized systems with a $\mathrm{K}$ deficit, our results are consistent with Berry et al. (2003) and Blake et al. (1999) who calculated negative K budgets in organic systems without any form of $\mathrm{K}$ application. Moreover, in a study of three long-term field experiments with mixed cropping systems over an 18-year period, Andrist-Rangel et al. (2007) reported negative K budgets (input minus crop uptake) for organic systems in the range of -22 to $-75 \mathrm{~kg}$ $\mathrm{K} \mathrm{ha}^{-1}$ year $^{-1}$. Based on comparisons of nutrient budgets, the balances could vary widely within a cropping system. However, as the general conclusion, alternative systems 
Fig. 3 Seasonal course of soil $\mathrm{CO}_{2}$ emission rates during the studied period. Error bars indicate standard error of the mean $(n=12$ plots per treatment and season). Respiration was measured for two consecutive artichoke-growing seasons at weekly intervals
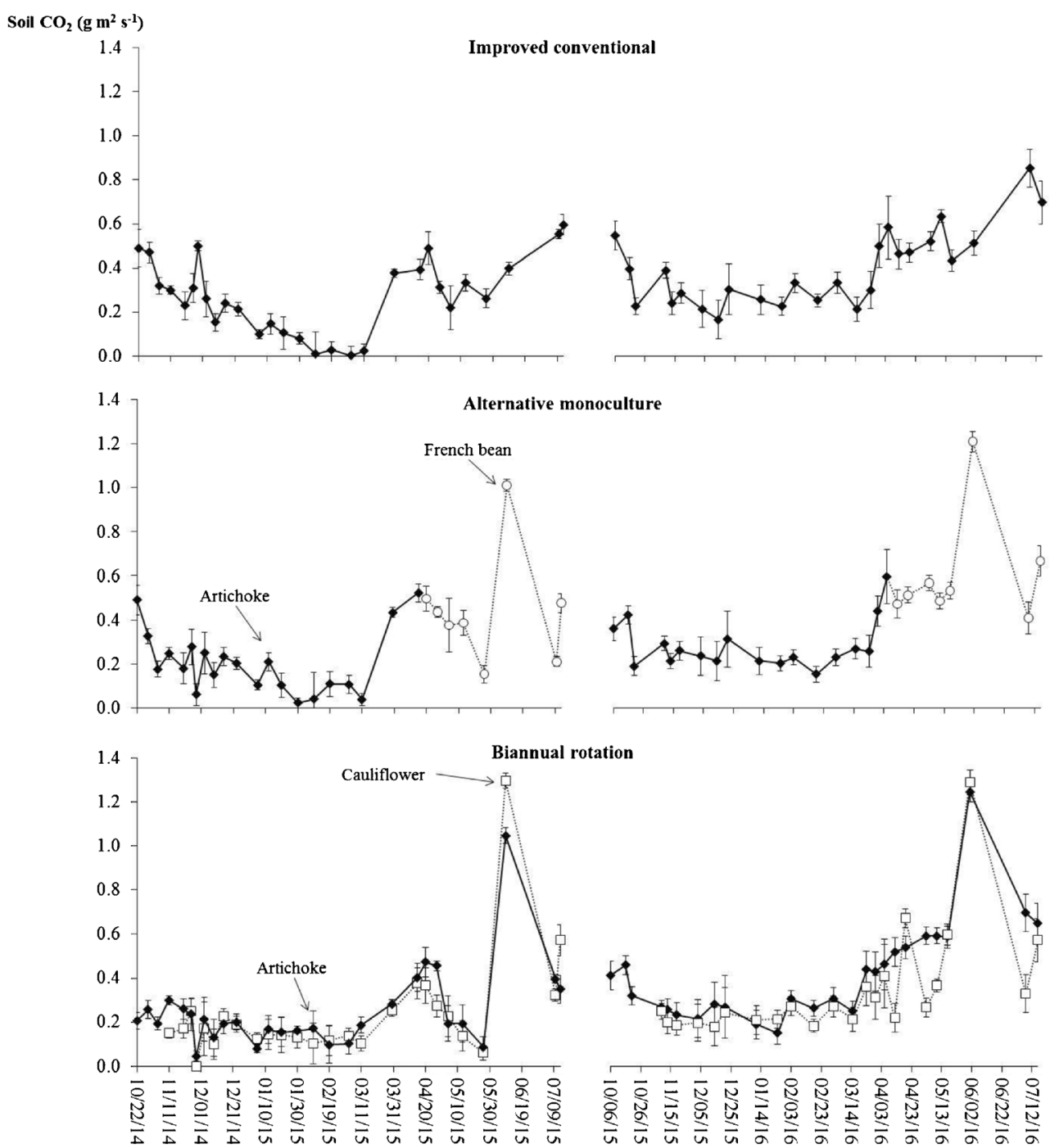

promoted smaller nutrient deficits or surpluses than those of the conventional system, which should be an advantage, provided that nutrient reserves are not lost with leaching. The benefits of crop residue retention on agronomic productivity and sustainability are particularly important in soils such as those in Mediterranean areas, which are prone to erosion, drought, high soil temperatures, crusting or surface sealing, and hard-setting on drying (Lal 2009).

\subsection{Soil respiration response to cropping systems}

Because the experiment was irrigated, soil water content was relatively stable over the study period and poorly correlated with soil respiration (data not shown); as a consequence, soil humidity was not considered further in the discussion of the results. In the improved conventional system, over both growing seasons, the lowest soil respiration values occurred during winter, and then values gradually increased from March and reached a maximum in July, in a pattern similar to that of soil temperature (Fig. 3). The lowest values of $\mathrm{CO}_{2}$ flux $(\leq 0.04 \mathrm{~g}$ $\mathrm{CO}_{2} \mathrm{~m}^{-2} \mathrm{~s}^{-1}$ ) were in the improved conventional system with little fluctuation during the measurement season. In the 2014 2015 growing season, for both alternative systems, two peaks per year occurred (1.04-1.30 $\mathrm{g} \mathrm{CO}_{2} \mathrm{~m}^{-2} \mathrm{~s}^{-1}$ for the biannual rotation and 1.01-1.21 $\mathrm{g} \mathrm{CO}_{2} \mathrm{~m}^{-2} \mathrm{~s}^{-1}$ for alternative monoculture) during the last 10 days of April and June. The soil respiration from systems with cover crops fluctuated more than that in the improved conventional system during 2014 2015 (Fig. 3). By contrast, in the 2015-2016 growing season, the three systems showed a similar pattern of soil respiration with significant differences between alternative systems and the improved conventional system only on the last two monitoring dates. The difference in soil $\mathrm{CO}_{2}$ emissions observed among treatments was most likely attributed to the difference in amount and quality of the residues added, which could have different effects on the biological properties and organic carbon mineralization of the soil (Iqbal et al. 2009; Mancinelli et al. 2013). In the alternative monoculture, in addition to the 
return of plant residues, the two peaks were also caused by soil tillage for seedbed preparation for the next crop cycle, as also observed by Schwartz et al. (2010) and West and Marland (2002). Furthermore, Mancinelli et al. (2010) found that the incorporation of cover crop biomass into soil caused an increase in soil $\mathrm{CO}_{2}$ emissions. In the biannual rotation, the first peak occurred at the conclusion of both primary crops (artichoke or cauliflower) plus cover crop in mid-April, and the second (at the end of June) was most likely due to a rapid mineralization phase based on the composition of plant residues $(\mathrm{C} / \mathrm{N}$ ratio below 20 is expected to result in net mineralization). These findings suggest that alternative systems rely on the management of crop and cover crop residues, and in our study, the release of nutrients from residue decomposition, both in the alternative monoculture and biannual rotation, was most likely synchronized with patterns of plant nutrient uptake in the following crop cycle. The amounts of nutrients returned to the soil from the mineralization of residues combined with the $\mathrm{N}$ fixed by leguminous plants might explain the yield performance of alternative systems in the long term. Moreover, whereas in alternative systems, nutrients are efficiently recycled through the soil food web with soil organic matter content maintained or increased, in the improved conventional system, we observed that distribution of amounts of $\mathrm{N}$ based on crop uptake was an adequate strategy to maintain yields and contribute to the increase of soil organic matter. Finally, compared with an unimproved conventional system (typically based on the removal of crop residues, which was not considered in our study), a reasonable conclusion is that the benefits described for the alternative systems would be more significant in the long term.

\section{Conclusions}

Traditional management of the Mediterranean artichokecropping system must be re-designed to avoid nutrient surpluses that cause head disorder and yield losses and environmental concerns. Our study addressed an important research gap regarding the effects of crop residue management, introduction of legume cover crops, and biannual rotation on the long-term stability of nutrient fluxes for artichoke cropping. Moreover, two alternative, more sustainable artichokecropping systems were specifically set up and proposed. Therefore, our 10-year study provided a long-term evaluation of different strategies for crop residue management aimed to reduce $\mathrm{N}$ surpluses in artichoke-cropping systems, which included no removal of crop residues coupled with efficient synthetic fertilizer applications (improved conventional), legume cover crop adoption (alternative monoculture), and crop rotation plus cover crop (biannual rotation). Results from the long-term field experiment indicated that the combined introduction of a legume cover crop and biannual rotation was more beneficial for a well-balanced $\mathrm{N}$ budget than conventional ( $\mathrm{N}$ surplus) and alternative monocultures (slight $\mathrm{N}$ deficit). Moreover, in the absence of synthetic fertilizers, the adoption of legume cover crops promoted valuable nutrient recycling without any decline in artichoke yield. Results also showed that fertility management using legume cover crops during artichoke production promoted similar soil quality compared with that of improved conventional practices based on incorporation of dry residuals into soil alone. Furthermore, results indicated that the use of fertility-building crops had the potential to maintain adequate soil quality in the alternative monoculture and biannual rotation systems. Compared with the improved conventional system, the different patterns of soil respiration measurements in the alternative systems indicated active decomposition processes of biomass. Overall, our findings highlight the importance of complementary sources of returned crop residues (primary crop and legume cover crop) for re-designed artichoke-cropping systems and provide novel information for producers. The adoption of modulated harvests in the intercropped legume (French bean) is suggested as an important tool to positively affect nutrient balance and economic returns. The complete evaluation of both amounts and specific chemical properties of root biomass from the different primary crops in the biannual rotation system requires investigation in future experiments.

Author contributions PAD analyzed the data and wrote the paper; MTT conducted the experimental work from 2014 to 2016, managed the long-term database, and wrote the paper; LS conducted the $\mathrm{N}$ fixation measurements and wrote the paper; MB conducted the experimental work from 2015 to 2016 and managed the long-term database; SC conducted the experimental work from 2014 to 2015 ; LD conducted the experimental work from 2006 to 2010; GS conducted the experimental work from 2014 to date; ESpa conducted the laboratory analysis from 2012 to 2015; ESpi conducted the experimental work from 2012 to 2014; GRU conducted the experimental work from 2006 to 2009; LL (corresponding author) conceived and designed the field experiment, supported experiment costs, analyzed the data, and wrote the paper. All authors read and approved the final manuscript.

\section{References}

Almagro M, López J, Querejeta-Mercader JI, Hernández T (2009) Temperature dependence of soil $\mathrm{CO}_{2}$ efflux is strongly modulated by seasonal patterns of moisture availability in a Mediterranean ecosystem. Soil Biol Biochem 41:594-605. https://doi.org/10. 1016/j.soilbio.2008.12.021

Andrist-Rangel Y, Edwards AC, Hillier S, Öborn I (2007) Long-term K dynamics in organic and conventional mixed cropping systems as related to management and soil properties. Agric Ecosyst Environ 122:413-426. https://doi.org/10.1016/j.agee.2007.02.007

AOAC (1995) Official methods of analysis. Association of Official Analytical Chemists, Washington

Berry M, Stockdale EA, Sylvester-Bradley R, Philipps L, Smith KA, Lord EI, Watson CA, Fortune S (2003) N, P and K budgets for crop rotations on nine organic farms in the UK. Soil Use Manag 19:112118. https://doi.org/10.1111/j.1475-2743.2003.tb00289.x 
Blake L, Mercik S, Koerschens M, Goulding KWT, Stempen S, Weigel A, Poulton PR, Powlson DS (1999) Potassium content in soil, uptake in plants and the potassium balance in three European longterm field experiments. Plant Soil 216:1-14

Calabrese N (2009) Impianto. In: Calabrese N (ed) Il carciofo e il cardo. Bayer Crop Science Inc, Bologna, p 167

Cameira MR, Mota M (2017) Nitrogen related diffuse pollution from horticulture production - mitigation practices and assessment strategies. Horticulturae 3:25. https://doi.org/10.3390/ horticulturae 3010025

Cavigelli MA, Thien SJ (2003) Phosphorus bioavailability following incorporation of green manure crops. J Environ Qual 67:1186-1194. https://doi.org/10.2136/sssaj2003.1186

Constantin J, Mary B, Laurent F, Aubrion G, Fontaine A, Kerveillant P, Beaudoin N (2010) Effects of catch crops, no till and reduced nitrogen fertilization on nitrogen leaching and balance in three long-term experiments. Agric Ecosyst Environ 135:268-278. https://oi.org/ 10.1016/j.agee.2009.10.005

Cotrufo MF, Wallenstein M, Boot MC, Denef K, Paul EA (2013) The microbial efficiency-matrix stabilization (MEMS) framework integrates plant litter decomposition with soil organic matter stabilization: do labile plant inputs form stable soil organic matter? Glob Chang Biol 19:988-995. https://doi.org/10.1111/gcb.12113

Duchene O, Vian JF, Celette F (2017) Intercropping with legume for agroecological cropping systems: complementarity and facilitation processes and the importance of soil microorganisms. A review. Agric Ecosyst Environ 240:148-161. https://doi.org/10.1016/j. agee.2017.02.019

EIP-AGRI Focus Group (2015) Soil organic matter in Mediterranean regions. http://www.ec.europa.

Emberger L, Gaussen G, Kassas M, De Philippis A (1962) Bioclimatic map of the Mediterranean region. UNESCO-FAO, Paris

Foury C (1967) Étude de la biologie florale de l'artichaut (Cynara scolymus L.); application à la sélection, 1ère partie: données sur la biologie florale. Ann Amèlior Plantes 17:357-373

Francois LE, Donovan TJ, Maas EV (1991) Calcium deficiency of artichoke buds in relation to salinity. HortSci 26:549-553

Gomiero T, Pimentel D, Paoletti MG (2011) Environmental impact of different agricultural management practices: conventional vs organic agriculture. Crit Rev Plant Sci 30:95-124. https://doi.org/10. 1080/07352689.2011.554355

Ierna A, Mauro RP, Mauromicale G (2012) Improved yield and nutrient efficiency in two globe artichoke genotypes by balancing nitrogen and phosphorus supply. Agron Sustain Dev 32:773-780. https://doi. org/10.1007/s13593-011-0048-7

Iqbal J, Hu R, Lin S, Hatano R, Feng M, Lu L, Ahamadou B, Du L (2009) $\mathrm{CO}_{2}$ emission in a subtropical red paddy soil (Ultisol) as affected by straw and N-fertilizer applications: a case study in Southern China. Agric Ecosyst Environ 131:292-302. https://doi.org/10.1016/j.agee. 2009.02.001

Italian Soil Science Society (2000) Metodi di analisi chimica del suolo. Franco Angeli, Milano

James BR (2005) Buffering capacity. In: Hillel D (ed) Encyclopedia of soils in the environment. Elsevier, Oxford, pp 142-147. https://doi. org/10.1016/B0-12-348530-4/00180-6

Kautz T, Amelung W, Ewert F, Gaiser T et al (2013) Nutrient acquisition from arable subsoils in temperate climates: a review. Soil Biol Biochem 57:1003-1022. https://doi.org/10.1016/j.soilbio.2012.09. 014

Kenward MG, Roger JH (1997) Small sample inference for fixed effects from restricted maximum likelihood. Biometrics 53:983-997. https://doi.org/10.2307/2533558

Korsaeth A (2012) N, P, and K budgets and changes in selected topsoil nutrients over 10 years in a long-term experiment with conventional and organic crop rotations. Appl Environ Soil Sci 2012:1-17. https://doi.org/10.1155/2012/539582
Lal R (2009) Challenges and opportunities in soil organic matter research. Eur J Soil Sci 60:158-169. https://doi.org/10.1111/j.1365-2389. 2008.01114.x

Leavitt MJ, Sheaffer CC, Wyse DL, Allan DL (2011) Rolled winter rye and hairy vetch cover crops lower weed density but reduce vegetable yields in no-tillage organic production. HortSci 46:387-395

Ledda L, Mameli MG, Milia M, Marras GF (2003) Influence of plant shading and ovoli typology on globe artichoke development, early production and head atrophy: preliminary results. Acta Hortic 660: 365-371. 10.17660/ActaHortic.2004.660.53.

Ledda L, Deligios PA, Farci R, Sulas L (2013) Biomass supply for energetic purpose from some Cardueae species grown in Mediterranean farming systems. Ind Crop Prod 47:218-226. https://doi.org/10. 1016/j.indcrop. 2013.03.013.

Lenzi A, Baldi A, Tesi R (2015) Artichoke (Cynara scolymus L.) as cashcover crop in an organic vegetable system. Acta Agric Slov 105:5360. 10.14720/aas.2015.105.1.06

Llorach R, Espín JC, Tomás-Barberán FA, Ferreres F (2002) Artichoke (Cynara scolymus L.) byproducts as a potential source of healthpromoting antioxidant phenolics. J Agric Food Chem 50:34583464. https://doi.org/10.1021/jf0200570

Mahmoud EK, Abd EL-Kader NK (2012) How the nitrogen fertilization dose affects the biochemical composition and net mineralization of the artichoke residues. J Soil Sci Plant Nutr 12:23-31. https://doi. org/10.4067/S0718-95162012000100003

Maltais-Landry G, Scow K, Brennan E, Torbert E, Vitousek P (2016) Higher flexibility in input N:P ratios results in more balanced phosphorus budgets in two long-term experimental agroecosystems. Agric Ecosyst Environ 223:197-210. https://doi.org/10.1016/j. agee.2016.03.007

Mancinelli R, Campiglia E, Di Tizio A, Marinari S (2010) Soil carbon dioxide emission and carbon content as affected by conventional and organic cropping systems in Mediterranean environment. Appl Soil Ecol 46:64-72. https://doi.org/10.1016/j.apsoil.2010.06.013

Mancinelli R, Marinari S, Di Felice V, Savin MC, Campiglia E (2013) Soil property, $\mathrm{CO}_{2}$ emission and aridity index as agroecological indicators to assess the mineralization of cover crop green manure in a Mediterranean environment. Ecol Indic 34:31-40. https://doi. org/10.1016/j.ecolind.2013.04.011

Markaki Z, Loye-Pilot MD, Violaki K, Benyahya L, Mihalopoulos N (2010) Variability of atmospheric deposition of dissolved nitrogen and phosphorus in the Mediterranean and possible link to the anomalous seawater N/P ratio. Mar Chem 120:187-194. https://doi.org/ 10.1016/j.marchem.2008.10.005

Mauro R, Di Nicola M, Longo AMG, Mauromicale G (2008) The effects of mist irrigation on biological and productive behaviour of globe artichoke. In: Santini A et al (eds) Irrigation in Mediterranean agriculture: challenges and innovation for the next decades. CIHEAM, Bari, pp 41-46

Montemurro F, Fiore A, Campanelli G, Tittarelli F, Ledda L, Canali S (2013) Organic fertilization, green manure, and vetch mulch to improve organic zucchini yield and quality. HortSci 48:1027-1033

Morselli L, Bernardi E, Vassura I, Passarini F, Tesini E (2008) Chemical composition of wet and dry atmospheric depositions in an urban environment: local, regional and long-range influences. J Atmos Chem 59:151-170. https://doi.org/10.1007/s10874-008-9099-9

Murungu FS, Chiduza C, Muchaonyerwa P, Mnkeni PNS (2011) Decomposition, nitrogen and phosphorus mineralization from winter-grown cover crop residues and suitability for a smallholder farming system in South Africa. Nutr Cycl Agroecosyst 89:115123. https://doi.org/10.1007/s10705-010-9381-5

Nastos PT, Alexakis D, Kanellopoulou HA, Kelepertsis AE (2007) Chemical composition of wet deposition in a Mediterranean site Athens, Greece related to the origin of air masses. J Atmos Chem 58:167-179. https://doi.org/10.1007/s10874-007-9085-7 
Nesme T, Brunault S, Mollier A, Pellerin S (2011) An analysis of farmers use of phosphorus fertiliser in industrial agriculture: a case study in the Bordeaux region (south-western France). Nutr Cycl Agroecosyst 91:99-108. https://doi.org/10.1007/s10705-011-9449-x

OECD (2007a) OECD nitrogen balance handbook. Eurostat, Paris

OECD (2007b) OECD phosphorus balance handbook. Eurostat, Paris

Ohm M, Paulsen HM, Moos JH, Eichler-Löbermann B (2017) Long-term negative phosphorus budgets in organic crop rotations deplete plantavailable phosphorus from soil. Agron Sustain Dev 37:17. https:// doi.org/10.1007/s13593-017-0425-y

Pavek PLS (2012) Plant guide for pea (Pisum sativum L.). USDA-Natural Resources Conservation Service, Pullman

Piras F (2013) Coding of phenological stages and dynamic of nutrient absorption in Cynara cardunculus var. scolymus. PhD Dissertation, University of Sassari, Italy.

Pisanu AB, Muntoni M, Ledda L (2009) Carciofo in Sardegna. In: Calabrese N (ed) Il carciofo e il cardo. Bayer Crop Science Inc, Bologna, pp 124-135

Sánchez de Cima D, Reintam E, Tein B, Eremeev V, Luik A (2015) Soil nutrient evolution during the first rotation in organic and conventional farming systems. Commun Soil Sci Plant Anal 46:26752687. https://doi.org/10.1080/00103624.2015.1089268

SAS Software (1999) Version 9.02. SAS Institute Inc, Cary

Schwartz RC, Baumhardt RL, Evett SR (2010) Tillage effects on soil water redistribution and bare soil evaporation throughout a season. Soil Tillage Res 110:221-229. https://doi.org/10.1016/j.still.2010. 07.015

Sgroi F, Fodera M, Di Trapani AM, Tudisco A, Testa R (2015) Profitability of artichoke growing in the Mediterranean area. HortSci 50:1349-1352

Shen P, Xu M, Zhang H, Yang X, Huang S, Zhang S, He X (2014) Longterm response of soil Olsen $\mathrm{P}$ and organic $\mathrm{C}$ to the depletion or addition of chemical and organic fertilizers. Catena 118:20-27. https://doi.org/10.1016/j.catena.2014.01.020

Shinohara T, Agehara S, Yoo KS, Leskovar DI (2011) Irrigation and nitrogen management of artichoke: yield, head quality, and phenolics. HortSci 46:377-386
Simpson RJ, Oberson A, Culvenor RA, Ryan MH, Veneklaas EJ, Lambers H, Lynch JP, Ryan PR, Delhaize E, Smith FA, Smith SE, Harvey PR, Richardson AE (2011) Strategies and agronomic interventions to improve the phosphorus-use efficiency of farming systems. Plant Soil 349:89-120. https://doi.org/10.1007/s11104-0110880-1

Spanu E, Deligios PA, Azara E, Delogu G, Ledda L (2017) Effects of alternative cropping systems on globe artichoke qualitative traits. J Sci Food Agric. https://doi.org/10.1002/jsfa.8558

Sulas L, Piluzza G, Rochon JJ, Goby JP, Greef JM, Solter U, Headon D, Scholefield D (2012) Assessing the potential for nutrient leaching from beneath grazed leguminous swards at four European sites. Grass Forage Sci 67:320-336. https://doi.org/10.1111/j.1365-2494. 2011.00842.x

Tonitto C, David MB, Drinkwater LE (2006) Replacing bare fallows with cover crops in fertilizer-intensive cropping systems: a meta-analysis of crop yield and N dynamics. Agric Ecosyst Environ 112:58-72. https://doi.org/10.1016/j.agee.2005.07.003

Turmel MS, Speratti A, Baudron F, Verhulst N, Govaerts B (2015) Crop residue management and soil health: a systems analysis. Agric Syst 134:6-16. https://doi.org/10.1016/j.agsy.2014.05.009

USDA (United States Department of Agriculture) (1999) Soil taxonomy: a basic systems of soil classification for making and interpreting soil surveys. In: USDA-NRCS agriculture handbook, 2nd edn. ftp://ftpfc.sc.egov.usda.gov/NSSC/Soil_Taxonomy/tax.pdf

Warembourg FR (1993) Nitrogen fixation in soil and plant systems. In: Knowles R, Blackburn TH (eds) Nitrogen isotope techniques. Academic Press, New York, pp 127-156

West TO, Marland G (2002) A synthesis of carbon sequestration carbon emissions, and net carbon flux in agriculture: comparing tillage practices in the United States. Agric Ecosyst Environ 91:217-232. https://doi.org/10.1016/S0167-8809(01)00233-X

Yan Z, Liu P, Li Y, Ma L, Alva A, Dou Z, Chen Q, Zhang F (2013) Phosphorus in China's intensive vegetable production systems: overfertilization, soil enrichment, and environmental implications. J Environ Qual 42:982-989. https://doi.org/10.2134/jeq2012.0463 